Проанализированы законодательные уступки светских и религиозных властей России по отношению к старообрядчеству. Рассмотрены некоторые исторические документы XVIII-XXI вв., отражающие вынужденные послабления государственной политики, направленные на достижение лояльности старообрядцев. Постепенное смягчение государственной политики по отношению к старообрядчеству было вызвано их постоянной борьбой за обретение равенства с другими социальными, конфессиональными группами России и улучшение своего правового, социального положения. В работе также приводятся выдержки из произведений главного идеолога старообрядчества и лучшего писателя XVII в. протопопа Аввакума Петровича.

Ключевые слова: старообрядчество, протопоп Аввакум, Республика Бурятия, правовое положение, церковная реформа.

\title{
E. V. Petrova, V. L. Petrov \\ IMPROVEMENT OF THE LEGAL STATUS OF OLD BELIEVERS IN RUSSIA AS A RESULT OF THEIR CENTURIES-LONG EFFORT FOR THE IMPLEMENTATION OF THE IDEAS OF PROTOPOPE AVVACUM
}

The article analyzes legislative concessions to the Old Believers by the secular and religious authorities of Russia. Some historical documents of the XVIII-XX centuries, reflecting the forced easing of state policy aimed at achieving the Old Believers' loyalty, are considered. The gradual softening of state policy towards the old believers was caused by their constant struggle to gain equality with other social and religious groups in Russia and improve their legal and social status. The article contains excerpts from the works of the main ideologist of the old believers and the best writer of the XVII century, Archpriest Avvakum Petrovich.

Keywords: Old Believers, protopope Avvakum, Republic of Buryatia, legal status, church reform.

Dусское старообрядчество появилось в истории России в середине XVII в., в Алексей Михайлович Романов и патриарх Русской православной церкви Никон. Сегодня в науке принято считать, что объективно церковных причин проведения реформы не было, но были политические предпосылки для еe реализации, главные из которых - вхождение Украины в состав России, где церковь жила уже

ПЕТРОВА Елена Викторовна - доктор социологических наук, ведущий научный сотрудник Федерального государственного бюджетного учреждения науки «Институт монголоведения, буддологии и тибетологии СО РАН» (г. Улан-Удэ, Россия). E-mail: elenapet_05@mail.ru.

ПЕТРОВ Виктор Леонтьевич - заслуженный учитель Российской Федерации, руководитель республиканской общественной организации «Центр изучения культуры» (г. Улан-Удэ, Россия). E-mail: Petrov.V.L.2011@mail.ru. 
по новогреческим новинам; желание царя и его окружения распространить свое влияние на весь православный мир в рамках реализации концепции «Москва третий Рим, а четвертому не бывать».

Однако резонанс, который получила реформа в обществе, был настолько глубок, что последствия этого события дошли до наших дней, находя свое проявление в функционировании старообрядческих поселений и общин как в нашей стране (г. Москва, г. Новозыбково, Алтай, Сибирь, Урал, Дальний Восток, Поморье), так и в ближнем и дальнем зарубежье (Прибалтика, США, Канада, Бразилия, Болгария, Польша, Румыния) [Петрова 2005: 26].

В год 400-летия со дня рождения протопопа Аввакума Петровича Кондратьева, главного идеолога старообрядчества и лучшего писателя XVII в., считаем необходимым хотя бы вкратце проанализировать часть исторических документов, в основе которых лежали вынужденные меры официальных властей, направленные на определенные уступки старообрядцам. Эти послабления официальной государственной политики по отношению к старообрядцам являлись результатом постоянной борьбы последних за свои гражданские и религиозные права и свободы. В статье рассмотрено, как шаг за шагом с 1653 г. до настоящего времени изменялось отношение российской церкви и государственных деятелей к возможности сохранять и соблюдать частью населения религиозные обряды и каноны, которые прежде (до 1653 г.) и на протяжении многих веков считались в России общепринятыми, традиционными и подлежащими неукоснительному исполнению.

Кроме того, поскольку в имеющейся научной литературе преимущественно освещаются преследования и гонения старообрядцев, причем достаточно широко и подробно, наша работа позволит взглянуть на проблему с несколько иной стороны: наряду с перманентными призывами церковной и государственной власти к уничтожению и притеснению старообрядцев эта же власть периодически предпринимала попытки добиться от старообрядцев лояльности путем определенных компромиссных решений, разрешений или снятия существующих ограничений.

Церковная реформа XVII в. разделила российское общество на тех, кто принял религиозные новины (новообрядцы), и тех, кто не согласился с ними (верные, старолюбцы, староверы, старообрядцы). Первоначально церковная власть старолюбцев «увещевала», даже проводила с ними споры на религиозные темы, но затем, видя, что их количество не уменьшается, приступила к «увещеваниям с пристрастием», то есть с использованием самых жестоких мер. А чтобы придать видимость законности церковным инновациям, состоялось множество «противораскольничьих» церковно-правительственных соборов (1654, 1656, 1665 гг., дважды в 1666, 1667, 1681 гг.), принявших решения об уничтожении всех, кто не согласен с новогреческим богослужением. Но наиболее жестокими в этом ряду считаются «12 статей» (1685 г.) царевны Софьи, в содержании которых звучал «узаконенный» призыв сжигать в срубах всех нераскаявшихся «раскольников» [Акты... 1836: 419-422].

Процесс первоначального становления российского старообрядчества как этноконфессиональной группы населения России выдвинул из своих рядов идеологов и руководителей - протопопа Аввакума Петровича Кондратьева, протопопа Казанского собора Ивана Неронова, дьякона Благовещенского собора Федора Иванова, епископа Павла Коломенского, муромского протопопа Логина, Гавриилу - священника из Нижнего Новгорода и др. Их беспримерное мужество и удивительная стойкость «верных» вызывали уважение и удивление даже у представителей другого лагеря - патриарше-синодальной Русской православной церкви. Так, один из крупнейших представителей научно-исследовательской мысли России конца 2-й половины 
XIX в. профессор Петр Семенович Смирнов писал о первых десятилетиях проведения церковной реформы: «Во главе стоял протопоп Аввакум. Человек несокрушимого здоровья, железной воли, редких дарований... Его знали везде и все; никто ... не имел так много учеников и почитателей, как Аввакум; преданность ему была безгранична, верили ему безусловно, его “умъ” называли “огненным” и “благодатным”, его наставления признавали во всем согласными “писанию”. Письменные запросы ... осаждали землянку “преосвященнаго” протопопа - и ответныя послания экс-протопопа наводнили раскольничий мир... Ему приходилось писать слишком много: вопрошавшимъ - ответъ, печальнымъ - утешение, обиженным - защиту, раскаявшимся - прощение. Читались и переписывались эти послания с большим увлечением: ученики извещали своего учителя, что они упиваются “сладостию” писаний его. Причина этого крылась между прочим в складе и форме последних. Это была речь человека глубоко убежденного; это были письма, подражавшие началом или концом писаниям апостолов и евангелистов; это был язык живой, та же устная беседа, выразительная и картинная, всегда меткая и характерная, всегда простая и понятная ... одно слово “по человеку”, одно сравнение или пословица говорили читателям больше, чем сказала бы масса доказательств. Таков был Аввакум...» [1898: 17].

В России не было принято «перечить» царю или ослушиваться патриарха, а если такое происходило, то обыкновенно для «бунтаря» заканчивалось либо казнью, либо ссылкой, - поэтому не принявших изменения реформы стали называть «раскольниками», «еретиками», «предтечами антихристовыми». В ответ на это протопоп Аввакум в «Пятой» челобитной царю Алексею Михайловичу писал: «Что есть ересь наша или кий раскол внесохом мы во церковь, якож ... о нас никонияня, нарицают раскольниками и еретиками в лукавом и богомерском Жезле, а инде и предотечами антихристовыми? Не постави им Господь греха сего, не ведят бо беднии, что творят. Ты самодержче, суд подымеши о сих всех, иже таково им дерзновение подавай на ны. Не вемы в себе ни следу ересей, коих пощади нас Сын Божий от такова нечестия и впредь, ниж раскольства: Бог сведетель и Пречистая Богородица и вси святии! Аще мы раскольники и еретики то и вси святии отцы наши и прежнии цари благочестивии и святейшия патриархи такови суть. О небо и земле, слыши глаголы сия потопныя и языки велеречивыя!» [Житие Аввакума... 1991: 93].

В ходе проведения церковной реформы РПЦ выбросила старообрядцев за церковную ограду, а государство лишило их всех гражданских прав. Однако столь жестокие меры не дали ожидаемых результатов - число несогласных с новинами постоянно увеличивалось, десятки тысяч бежали за границу на территорию Польши, великого княжества Литовского и других сопредельных государств, продолжая сохранять верность прежним церковным обрядам, да и для государства репрессии на религиозной почве не приносили благ, наоборот, его ослабляли.

Впервые это понял Петр I и в 1716 г. подписал указ, благодаря которому устанавливалась процедура «легализации» «раскольников» через специальное налогообложение - двойной подушный оклад, то есть со всех записных старообрядцев предписывалось взимать государственную подать в двойном размере; также им было разрешено селиться в определенных местах, а с 14 февраля давался месячный срок для «добровольной» записи старообрядцев в раскол. В этом же году произошла отмена официального предписания сожжения раскольников. Период действия законодательства в России, предусматривающего обязательную запись в двойной «раскольничий» оклад, растянулся с 1716 до 1782 г., когда он был отменен [Русское православие... 1989: 254]. 
Конечно, это были первые шаги со стороны светских и церковных властей России по ограничению, хотя бы небольшому, гонений против людей, оставшихся верными религиозным традициям своих отцов и дедов, взглядам и писаниям Аввакума. Данные послабления, хотя и в незначительной мере, но расширяли статус последователей Аввакума в общегражданском понимании того времени. Этот процесс заметно обозначился при царствовании Петра III - 29 января 1762 г. он издал указ, согласно которому староверам давалось право из Речи Посполитой возвращаться в Россию и селиться в Сибири, в Барабинской степи и подобных местах. Им было обещано «никакого в содержании закона по их обыкновению не чинить» [ПСЗ Т. 15, № 11420: 894-895]. А в феврале того же года власти объявили старообрядцам, что все следствия об их самосожжении прекращаются с той целью, чтобы они, не опасаясь наказания, «оставили это душепогибельное намерение и разошлись в домы» [Там же, № 11434: 907-908].

После очередного дворцового переворота и отстранения от власти Петра III новая императрица Екатерина II в отношении старообрядцев продолжила политику послабления: ее указ от 19 июня 1762 г. содержал новые призывы к «беглым людям» возвращаться в Россию; в октябре того же года был отменен указ 1722 г. Петра I, согласно которому «раскольников нижегородских, направляемых в Сибирь, возвратить в Роогевик» для строительства военного порта и военной базы флота. Последующие указы и манифесты Екатерины провозглашали большую терпимость к староверам, а также расширение их социальных прав [Поташенко 2006: 137]. В конце 1763 г. Екатерина II закрыла Раскольническую контору, существовавшую с 1725 г. и собиравшую со старообрядцев налоги двойной подушной и с ношения бороды [ПС3 Т. 16, № 11989: 466]. Поэтому уже с 1764 г. было разрешено «записным раскольникам» носить бороды и неуказанное платье, не оплачивая это право в казну [Там же, № 12067: 596].

Также существует любопытное издание - «Речь императрицы Екатерины Великой о старообрядчестве, сказанная на общей конференции Синода и Сената 15 сентября 1763 года», в которой императрица обещает старообрядцам свободу вероисповедания. Однако следует отметить, что в научной литературе ведется дискуссия по поводу достоверности речи и реальности выступления императрицы: некоторые исследователи считают, что Екатерина не выступала на конференции и подобную речь не произносила, а ее текст - всего лишь хорошая, качественная подделка [Иванов-Ордынский 2010]. Тем не менее ссылки на этот документ приведем, настолько он впечатляет своей эмоциональностью и логичностью [Речь императрицы... 1912; Поташенко 2006: 201].

В последующие годы Екатерина II также проявляла лояльность по отношению к старообрядцам - так, во время ее путешествия «в мае 1767 года по Волге в Балахне купец Осокин (раскольник) поднес монаршьей особе хлеб и соль, различные фрукты и две чернильницы с медным прибором. Камер-фурьерским журналом зафиксировано, что жена Осокина еще два раза - 21 и 22 мая - подойдет к руке императрицы. 22 мая государыня жалует к руке старообрядцев наряду с представителями дворянства, купечества, духовенства. Они, как и другие, подносят ей хлеб-соль с серебряной «солоницей». Во всех остальных путешествиях Екатерины II (в Белоруссию и Крым) «раскольники» также участвуют в церемониале встреч Екатерины II и подносят ей хлеб-соль [Ибнеева 2005: 28].

В 1769 г. Екатериной II был принят закон «О допущении раскольников к присяге и свидетельству по спорам с малороссийскими владельцами о грунтах» [ПСЗ Т. 18, № 13255: 840-841]; в 1771 г. в Москве легально образованы две старооб- 
рядческие общины - Преображенская и Рогожская, сохранившиеся до настоящего времени [Распонин]; в 1782 г. старообрядцев наконец-то освобождают от двойного подушного оклада [ПСЗ Т. 21, № 15581: 745]; с 1783 г. происходит легализация старообрядческих типографий в России: издан указ о «Вольных типографиях» [Там же, № 15634: 792]. В этом же году запрещают употреблять наименование «раскольник» в письменных актах и «в разговоре», а с 1790 г. - в официальных документах; с 1785 г. стало возможным избирать старообрядцев на общественные должности («О дозволении выбирать раскольников в городовыя службы на основании Городоваго Положения») [Там же Т. 22, № 16238: 437].

Император Павел I также внес свой вклад в процесс примирения Синода и Сената со старообрядчеством. Так, 21 января 1799 г. было обнародовано предписание, «... чтобы впредь отбираемые у старообрядцев книги, ежели они ничего в себе противнаго святой церкви и обрядам заключать не будут, отдавались хозяевам их обратно», в то время как старообрядческие книги, наполненные «ругательствами противу святой церкви», рекомендовалось «отбирать и хранить в консистории» [Полное собрание... 1915: 338]. А годом раньше он дозволил «Нижегородской епархии старообрядцам иметь священников и церковь для отправления в ней служения по старопечатным книгам» [Там же: 175] в рамках реализации концепции единоверия.

Эту традицию общения со старообрядцами продолжил и царь Александр I, не раз встречавшийся с ними и жертвовавший на монастыри, а в 1813 г. посетивший по пути из Парижа в Санкт-Петербург старообрядческий Федосеевский храм в Литве [Поташенко 2006: 325]. В 1811-1818 гг. старообрядцы возвращаются из-за границы в Россию для поселения в г. Измаил после указа Александра I от 25 июля 1811 г., согласно которому «им даруется вечное прощение в прежних их винах против Государя и Отечества ... гарантируются большие льготы и привилегии социально-экономического характера ... а также свобода в отправлении своих обрядов и строительстве церквей» [Пригарин 2012: 5-16]. В 1820 г. вышло постановление «О купеческих и мещанских выборах из раскольников» [Собрание постановлений... 1875: 61-62].

Александр II приглашал в Зимний дворец представителей Рогожской и Преображенской старообрядческих общин в знак благодарности за их поддержку во время Польского восстания [Русское православие... 1989: 370]; в период его правления с 1874 г. была разрешена гражданская метрическая запись брака, рождения и смерти старообрядцев [Там же: 369].

Николай II 17 апреля 1905 г. издал указ «Об укреплении начал веротерпимости» [ПСЗ Т. 25, № 26125: 257-258], содержание которого имело особое значение для всего российского старообрядчества: не полностью, но все же довольно широко последователи Аввакума получили свободу строить свои культовые учреждения, проводить в них моления по старым обрядам, завещанным им их дедами до проведения реформы; учить и воспитывать своих детей в том духовном пространстве, которое они сохранили; уже в который раз предлагалось вместо слова «раскольник» употреблять «старообрядец».

Указ, на наш взгляд, следует рассматривать как вынужденную уступку со стороны царя, его окружения, Синода и как успешный результат многовекового противостояния старообрядческого общества России с мощным государственно-церковным аппаратом за свою религиозную и гражданскую свободу. Старообрядцы сумели пройти этот большой путь благодаря заветам Аввакума: «Стойте твердо в вере и незыблемо страха же человеческаго не убойтеся, не ужасайтеся, Господа же Бога нашего святите в сердцах ваших, и Той будет нам во освящение, яко с нами Бог, 
и уповающе будет нань, и спасемся Его ради, яко с нами Бог» [Житие Аваакума... 1991: 135].

Через несколько дней после выхода в свет указа о веротерпимости Николай II записал в своем дневнике: «Христосовался со старообрядцами» [Дневники императора... 1991: 258]. В последние годы правления он имел личную охрану, сформированную из старообрядцев. «Когда представители Государственной Думы Гучков и Шульгин прибыли в ставку Николая и потребовали отречения от престола, вся охрана царя, состоявшая из казаков-староверов, умоляла его не отрекаться. Русские богатыри, прошедшие не одну войну, со слезами на глазах упали на колени и молили царя остаться. Очевидцы события передают, что последними словами царя перед отречением были: «Мне не простят старообрядцы, что я изменил своей клятве» [Митрополит Корнилий...].

Временное правительство России в марте 1917 г. объявляет о равенстве всех религий перед законом и отмене любых религиозных ограничений, издав постановление «Об отмене вероисповедных и национальных ограничений» [Сборник указов... 1917: 46-49].

Период с 1905 по 1917 г. старообрядцы России использовали с наивысшим результатом. Почти во всех местах их компактного проживания открылись молитвенные дома, часовни или церкви. Но история поступила с последователями протопопа Аввакума не совсем справедливо, отпустив им для полной религиозной самореализации всего несколько лет. Началась Первая мировая война, и ресурсы страны были брошены на фронт.

Лишь в 1929 г. РПЦ признает, что богослужебные книги, напечатанные при первых пяти патриархах (до 1653 г.), являются истинно православными, а порицательные выражения о старых обрядах «отвергаются» [Аторин].

На наш взгляд, только изучая произведения Аввакума, можно приблизиться к правильному пониманию истоков общероссийского старообрядческого движения. Вся жизнь протопопа была наполнена борьбой за правду, состояла из беспрерывной череды страданий во имя искупления грехов окружающих. Аввакумом руководило испепеляющее и душу и сердце стремление к истине, стремление, которое на протяжении всей его жизни было в абсолютной степени сильнее так называемого обыденного благоразумия и вело его по жизненному предназначению, указанному промыслом божьим. На Руси таких людей называли страстотерпцами. Сосланный в «тундряной» и «студеный» Пустозерск, посаженный в сруб, а затем брошенный в земляную яму, Аввакум не пал духом. «Осыпанный» мерзлой землей, лишенный самого необходимого, без книг, протопоп подвижнически нес свой крест. Не имея возможности произносить церковные проповеди, узник царя заменил их пером, а не случалось «оного» под рукой - писал «в темнице лучиной». Его церковью стала вся Русь, а его письменные проповеди слушала, вчитываясь в них, большая часть населения. Из-за полярного круга, из пустозерской «ямы» начиненные суровым религиозно-пропагандистским духом послания Аввакума разными путями доставлялись в Москву, а затем тайными каналами по России. Огненные слова, рожденные горячим сердцем среди ледяной пустыни, подобно искрам возжигали души его сторонников и последователей, «духовных детей» [Петров 2007: 16].

В своих челобитных царю протопоп разъяснял, что если те, кто придерживается старых обрядов, - «раскольники и «еретики», то «святые отцы наши», «цари благочестивые» и «святейшие патриархи таковы суть». С тех пор в спорах новообрядцев и старообрядцев прошло много времени, прежде чем вначале патриаршая, затем синодальная, позднее вновь патриаршая православная церковь России поняла 
эту, казалось бы, простую истину. Слишком долго думали высшие иерархи - сколько за это время было убито, сожжено и покалечено людей, жестоко и беспричинно поломано человеческих судеб, счет которых идет на десятки, сотни тысяч, а может быть миллионы. И только в мае 1971 г. на Поместном соборе РПЦ официально заявила, что церковная реформа патриарха Никона представляла собой «крупную и спешную ломку русской церковной обрядности и была предпринята в силу ошибочных взглядов на обрядовые различия как на различия в вере» [Аторин]. Выходит, что после этих шагов, освещающих истину, удаленную от нас на несколько веков, раскольниками следует считать не последователей и сторонников протопопа Аввакума, а тех, кто провел эту «спешную ломку русской церковной обрядности», следуя «ошибочным взглядам на обрядовые различия».

В 1974 г. собор епископов РПЦЗ также объявил, что все «клятвы» (т. е. проклятия в отношении старообрядцев), принятые ранее РПЦ, являются «недействительными», и «призвал не возобновлять обрядовых споров». В 2000 г. РПЦЗ вновь обратилась к старообрядцам с покаянием за преследования: «... Мы глубоко сожалеем о тех жестокостях, которые были причинены приверженцам старого обряда; о тех преследованиях со стороны гражданских властей, которые вдохновлялись и некоторыми из наших предшественников в иерархии Российской Церкви только за любовь старообрядцев к преданию, принятому от благочестивых предков, за ревностное хранение его... И, несмотря на это, хотя наша иерархия и наши верующие никогда не участвовали в преследованиях и насилиях, причиненных старообрядцам, мы хотим воспользоваться и ныне данным случаем, дабы испросить у них прощения за тех, кто презрительно относился к их благочестивым отцам... Простите, братья и сестры наши, прегрешения, причиненные вам ненавистью. Не считайте нас сообщниками в грехах наших предшественников, не возлагайте горечь на нас за невоздержные деяния их. Хотя мы потомки гонителей ваших, но неповинны в причиненных вам бедствиях. Простите обиды, чтобы и мы были свободны от упрека, тяготеющего над ними. Мы кланяемся вам в ноги и препоручаем себя вашим молитвам. Простите оскорбивших вас безрассудным насилием, ибо нашими устами они раскаялись в содеянном вам и испрашивают прощения» [Послание Собора...].

Был в истории российского старообрядчества еще и советский период, когда, возможно, старообрядчество потеряло больше, чем за все времена царской России. С приходом советской власти началось тотальное уничтожение религии, без различия «старых» или «новых обрядов». Под общий каток государственной машины, которая руководствовалась лозунгом «Религия - дурман для народа», попали и старообрядцы.

К примеру, в Бурятии по состоянию на 1 октября 1930 г. в Верхнеудинском районе (Тарбагатайский, Мухоршибирский, Хоринский) обществ верующих старообрядцев (поповцы, беспоповцы) было 48, молитвенных зданий - 43, служителей культа - 49, всего верующих 22340 чел. без учета Хоринского района, по которому статистических данных в архиве не было [Петрова 1999: 97-98]. К 1990 г. культовых зданий у старообрядцев, где бы проводились моления открыто и официально, как и религиозных обществ, в республике не сохранилось. Служители культа в большинстве случаев были репрессированы, но в г. Улан-Удэ и некоторых районах республики работали уставщики, к помощи которых прибегали семейские, в основном для совершения похоронных обрядов. Со стороны государственной власти в советское время поощрялось преимущественно хоровое пение семейских, научные исследования проводились по сбору фольклорного материала (песни, легенды, 
говор). Другие элементы культуры старообрядцев были объявлены «пережитком прошлого», «консерватизмом», «мракобесием», и даже в научной литературе того времени можно встретить подобные высказывания, в т. ч. и у известных выходцев из старообрядцев.

Все изменилось в 90-е гг. XX в. Так, в мае 1993 г. в Бурятии прошел первый съезд старообрядцев Забайкалья, в октябре 1995 г. - Дни культуры семейских, в апреле 1998 г. проведена первая республиканская краеведческая конференция школьников «Семейские в панораме веков», в этом же году состоялось открытие первой действующей старообрядческой (беглопоповцы) церкви в честь святителя Николая Чудотворца в с. Куйтун Тарбагатайского района. Через год прошла вторая республиканская краеведческая конференция школьников «Семейские в панораме веков». В 2000 г. была организована региональная научно-практическая конференция «История, культура, язык старообрядцев Забайкалья», в июне 2001 г. с большим успехом проведена третья международная научно-практическая конференция «Старообрядчество: история и современность, местные традиции, русские и зарубежные связи». В 2001 г. вышло Постановление Правительства Республики Бурятия № 198 от 04.06.2001 об утверждении республиканской целевой программы «Изучение, сохранение и развитие культуры семейских (2001-2006 гг.)» и началось время ее реализации. Постепенно открываются старообрядческие храмы - в селах Хасурта, Куйтун, Тарбагатай, Новый Заган, Бичура, г. Улан-Удэ [Петрова 2005].

Крупнейшим событием можно считать первую международную встречу старообрядцев мира «Путь Аввакума», состоявшуюся в 2007 г. в Бурятии, приуроченную к 350-летию ссылки в Забайкалье и Даурию защитника и ревнителя «древляго благочестия», выдающейся исторической личности XVII в. протопопа Аввакума, который с 1657 по 1662 г. находился в Забайкалье и похоронил здесь двух сыновей. В 2015 г. прошла вторая международная встреча старообрядцев [Старообрядцы (семейские)... 2015: 208-223].

Аввакум Петрович стал невольным участником экспедиции в Забайкалье под руководством воеводы Афанасия Пашкова, он два раза прошел по рекам Селенга и Хилок, терпя гонения, хулу, побои и страдания от воеводы. В 1657 г., миновав «Байкалово море», экспедиция пошла против течения Селенги к месту, где в нее впадает Хилок, а дальше вверх по Хилку [Артемьев 2003: 137]. Вот как сам Аввакум описывал свои злоключения: «По реке по Хилку заставил меня лямку тянуть; зело нужен ход ею был: и поесть неколи было, нежели спать; целое лето бились против воды. От тяготы водяныя в осень у людей стали и у меня ноги пухнуть и живот посинял, а на другое лето и умирать стали от воды. Два лета бродил в воде, а зимами волочился за волоки, чрез хребты. На том же Хилке в третье лето тонул: барку от берегу отторвало; людские стоят, а меня понесло; жена и дети остались на берегу... Несло с версту и больши, да переняли; все розмыло до крохи ... На Нерче-реке все люди з голоду померли, осталось небольшое место. По степям скитаяся и по лесу, траву и корение копали, а мы с ними же, а зимой сосну... Два у меня сына в тех умерли нуждах. Не велики были, да, однако, детки... А он Афонасей, наветуя, мне безпрестанно смерти ищет» [Житие Аввакума... 1991: 43-45].

Второй раз через земли, где жили «браты», протопоп Аввакум возвращался из Нерчинска (1662 г.). Когда экспедиция подходила к истокам Хилка, то воеводе Пашкову «перемена пришла» и протопопу «грамота пришла». Велено было им обоим ехать «к Русе». Воевода не взял с собою страдальца с его семьей. Да и сам Аввакум «убоялся с ним плыть». Работая над своим «Житием», он объяснял причину этого так: «Среди моря бы велел с судна пехнуть, а сказал бы, бытто сам ввалился; того 
ради и сам я с ним не порадел. Он в дощениках поплыл с людьми и с ружьем, а я, месяц спустя после ево, набрав старых, и раненых, и больных, кои там негодны, человек $з$ десяток, да я с семьею - семнатцеть человек, - в лотку седше, уповая на Христа и крест поставя на носу, поехали, ничево не боясь» [Житие Аввакума... 1991: 50]. Все благополучно до «Байкалова моря доплыли», починили лодку, сшили парус и «пошли через море». Внезапно налетела «на море погода» и «мы гребми перегреблися». Буря разыгралась и едва нашли место на берегу «от волн восходящих».

Далее в «Житии» идет великолепное описание берега Байкала, которое высоко оценили Ф. М. Достоевский, И. А. Гончаров, И. С. Лесков, И. А. Бунин, Алексей и Лев Толстые: «Около его горы высокия, утесы каменныя, и зело высоки, - дватцеть тысящ верст и больши волочился, а не видал нигде таких гор. На верху их полатки и повалуши, врата и столпы, и ограда... Чеснок на них и лук ростет больши романовскаго и слаток добре... А во дворах травы красны и цветны, и благовонны зело. Птиц зело много - гусей и лебедей, - по морю, яко снег плавает. Рыба в нем - осетры и таймени, стерледи, омули и сиги и прочих родов много» [Там же: 51]. Можно сказать, что до сих пор берега Селенги, Хилка, Байкала помнят быструю поступь, голос и дыхание протопопа Аввакума.

Итак, мы проанализировали, как старообрядчество России на протяжении четырех веков двигалось к гражданскому и религиозному равноправию с другими социальными и религиозными группами россиян. Серьезным достижением на этом пути является встреча с высшим руководителем России - Президент России Владимир Путин 31 мая 2017 г. почти целый день провел в духовном центре старообрядцев в Рогожской слободе, где обсудил с митрополитом одной из старообрядческих церквей (РПСЦ) Корнилием проблемы развития старообрядчества. Встреча имела далеко идущие позитивные последствия: «Президент рассмотрел обращение митрополита о праздновании 400-летия протопопа Аввакума, поддержал инициативу и дал поручение Правительству России выбрать те формы помощи, которые бы устроили всех в проведении этого мероприятия».

Президент сказал, что это «значимое событие» станет консолидирующим фактором для всего старообрядческого мира, а представители разных староверческих согласий «сосредоточат свои усилия» и используют юбилей для пропаганды «исконных русских духовных ценностей» [Впервые после раскола; Власти помогут старообрядцам...]. В дальнейшем эту инициативу поддержали Русская древлеправославная и Древлеправославная поморская церкви. Такая высокая и закономерная оценка духовной роли старообрядцев и их вклада в сохранение русской культуры, данная Президентом России, перекликается через сотни лет со словами Аввакума, которые он писал в своем «Житии», обращаясь к царю Алексею Михайловичу: «Ты ведь, Михайлович, русак, а не грек, говори своим природным языком; не уничижай ево и в церкви, и в дому и в пословицах. Любит нас бог не меньше греков...» [Житие Аввакума... 1991: 10].

«Течет время, одно поколение сменяет другое, но как свет во тьме притягивает наше внимание, наши души это загадочное, необычное явление, которое в скрижалях людской памяти высечено кратко и четко - житие и деяния протопопа Аввакума. Они не канули бесследно в бесконечную лету. Сквозь завесу времени, сквозь толщу веков, вопреки всевозможным приходящим и уходящим идеологиям, они прорываются к нам, живущим в XXI веке, чтобы воссиять путеводными звездами для тех, кто возвращается к историческим корням своего народа, к его истокам, кто повседневно ощущает свою связь с предками, кто сохраняет и развивает в современных 
условиях богатство родной русской культуры. Через 309 лет после казни, 5 июня 1991 г. протопоп Аввакум “вернулся" в родное село Григорово. На высоком холме, под лучами яркого солнца вспыхнул бронзою “огненный протопоп”. К своему подножию он собрал вместе и потомков продолжателей древлеправославной веры, и потомков гонителей на нее не только для того, чтобы доказать “свою правду”, но и для того, чтобы примирить всех во Христе» [Петров 2007: 19].

В юбилейный год со дня рождения протопопа Аввакума мы говорим о процессе консолидации старообрядческого мира, и праздничные мероприятия, запланированные по всей стране, являются формой современного религиозного согласия, к которому протопоп Аввакум призывал еще царя Алексея Михайловича, когда, отстаивая право старолюбцев на свободу своей религиозной совести - «боля о законе своем», утверждал, что нельзя «огнем и кнутом, да виселицею в веру приводить», однако в то время он так и не был услышан [Житие Аввакума... 1991: 16].

Постепенное смягчение государственной политики по отношению к старообрядчеству было вызвано их постоянной борьбой за обретение равенства с другими социальными и конфессиональными группами России. Правители России под давлением старообрядческой общественности на протяжении нескольких веков вынуждены были реализовывать законодательные уступки старообрядчеству, тем самым улучшая их правовое и социальное положение. Но, несмотря на это, даже сегодня есть вопросы, которые еще не решены. Надеемся, что юбилей протопопа Аввакума Петровича не только явится праздником для всех старообрядцев мира, но и позволит урегулировать существующие проблемы.

\section{Источники и литература}

Акты, собранные в библиотеках и архивах Российской империи Археографическою экспедицией Академии наук. Т. 4. - СПб.: Тип. ІІ Отделения Собственной Е. И. В. Канцелярии. $-1836 .-654$ с.

Полное собрание законов Российской империи. Т. 15. № 11420, 11434; т. 16. № 11989, 12067; т. 18. № 13255; т. 21. № 15581, 15634, 16238; т. 22. № 16238; т. 25 . № 26125 [Электронный ресурс]. - Режим доступа: http://nlr.ru/e-res/law_r/search.php.

Полное собрание постановлений и распоряжений по ведомству православного исповедания Российской империи. Царствование государя императора Павла Перваго. 6 ноября 1796 - 11 марта 1801 г. - Петроград: Тип. М. П. Фроловой, 1915. - 790 с.

Послание Собора РПЦЗ 2000 года «к приверженцам старых обрядов» [Электронный pecypc]. - Режим доступа: https://kandi-bober.livejournal.com/76515.html.

Сборник указов и постановлений Временного правительства. Вып. 1. Отд. II. № 32. Пг.: Гос. тип., 1917.

Собрание постановлений по части раскола. Постановления Министерства внутренних дел. Т. 1. - СПб.: Тип. М-ва внутренних дел, 1875. - 384 с.

Артемьев А. Р. Даурская ссылка протопопа Аввакума / А. Р. Артемьев // Вопросы истории. - 2003. - № 5. - С. 132-144.

Аторин Р. Ю. Поместный собор РПЦ 1971 года в деле развития конфессиональных отношений между Московским патриархатом и старообрядчеством [Электронный ресурс] / P. Ю. Аторин. - Режим доступа: http://rpsc.ru/publications/history/atorin_pomestnyj_sobor 1971/

Впервые после раскола [Электронный ресурс]. - Режим доступа: https://enta.ru/ articles/2017/05/31/old_believers/

Власти помогут старообрядцам отпраздновать юбилей протопопа Аввакума [Электронный ресурс]. - Режим доступа: https://ria.ru/20160623/1449858177.html.

Дневники императора Николая II. - М.: Орбита, 1991. - 755 с. 
Отечественная история

Житие Аввакума и другие его сочинения / сост., вступ. ст. и коммент. А. Н. Робинсон. М.: Сов. Россия, 1991. - 368 с.

Ибнеева Г. В. Старообрядческое население Нижегородского края: опыт политического взаимодействия / Г. В. Ибнеева // Православный собеседник. - Вып. 1(9), - 2005. - С. 72-98. Иванов-Ордынский $B$. Фальсификация или откровения просвещенной императрицы? / В. Иванов-Ордынский [Электронный ресурс]. - Режим доступа: https://vk.com/ topic-10399682_22777022.

Митрополит Корнилий: участие старообрядцев в революции - миф [Электронный ресурс]. - Режим доступа: https://ria.ru/20170203/1487123742.html.

Петров В. Л. Краткое слово о протопопе Аввакуме / В. Л. Петров // История и культура семейских Забайкалья. Хрестоматия. Ч. ІІ. - Улан-Удэ: Бэлиг, 2007. - С. 8-20.

Петрова E. B. Социокультурная адаптация семейских Забайкалья (этносоциологический анализ) / Е. В. Петрова. - Улан-Удэ: Изд-во БНЦ СО РАН, 1999. - 127 с.

Петрова Е. В. Современное забайкальское старообрядчество: уч. пос. / Е. В. Петрова. - Улан-Удэ: Изд-во БГУ, 2005. - 182 с.

Поташенко Г. В. Староверие в Литве: вторая половина XVII - начало IX вв.: исследования, документы и материалы / Г. В. Поташенко. - Vilnius: Aidai, 2006. - 543 с.

Пригарин А. А. Русско-турецкая война 1806-1812 гг. и судьбы некрасовцев / А. А. Пригарин // Русин. - 2012. - № 2(28). - С. 5-16.

Распонин И. Старообрядчество в XVIII-XIX [Электронный ресурс] / И. Распонин. - Pежим доступа: http://rpsc.ru/publications/history/staroobrjadchestvo_xviii-xix/

Речь императрицы Екатерины Великой о старообрядчестве, сказанная на общей конференции Синода и Сената 15 сентября 1763 года. - М.: Тип. П. П. Рябушинскаго, 1912. - 44 с.

Русское православие: вехи истории / науч. ред. А. И. Клибанов. - М: Политиздат, 1989. $-719 \mathrm{c}$.

Смирнов П. С. Внутренние вопросы в расколе в XVII в. Исследование из начальной истории раскола по вновь открытым памятникам, изданным и рукописным / П. С. Смирнов. - СПб.: Печатня С. П. Яковлева, 1898. - 517 с.

Старообрядцы (семейские) Бурятии: историко-культурный энциклопедический справочник. - Улан-Удэ: Экос, 2015. - 264 с.

\section{References}

Akty, sobrannye v bibliotekah i arhivah Rossijskoj imperii Arheograficheskoyu ekspediciej Akademii nauk. T. 4. - SPb.: Tip. II Otdeleniya Sobstvennoj E. I. V. Kancelyarii. - 1836. - 654 s.

Polnoe sobranie zakonov Rossijskoj imperii. T. 15. № 11420, 11434; t. 16. № 11989, 12067; t. 18. № 13255; t. 21. № 15581, 15634, 16238; t. 22. № 16238; t. 25 . № 26125 [Elektronnyj resurs]. - Rezhim dostupa: http://nlr.ru/e-res/law_r/search.php.

Polnoe sobranie postanovlenij i rasporyazhenij po vedomstvu pravoslavnogo ispovedaniya Rossijskoj imperii. Carstvovanie gosudarya imperatora Pavla Pervago. 6 noyabrya 1796 - 11 marta 1801 g. - Petrograd: Tip. M. P. Frolovoj, 1915. - 790 s.

Poslanie Sobora RPCZ 2000 goda «k priverzhencam staryh obryadov» [Elektronnyj resurs]. - Rezhim dostupa: https://kandi-bober.livejournal.com/76515.html.

Sbornik ukazov i postanovlenij Vremennogo pravitel'stva. Vyp. 1. Otd. II. № 32. - Pg.: Gos. tip., 1917.

Sobranie postanovlenij po chasti raskola. Postanovleniya Ministerstva vnutrennih del. T. 1. SPb.: Tip. M-va vnutrennih del, 1875. - 384 s.

Artem'ev A. R. Daurskaya ssylka protopopa Avvakuma / A. R. Artem'ev // Voprosy istorii. 2003. - № 5. - S. 132-144.

Atorin R. Yu. Pomestnyj sobor RPC 1971 goda v dele razvitiya konfessional'nyh otnoshenij mezhdu Moskovskim patriarhatom i staroobryadchestvom [Elektronnyj resurs] / R. Yu. Atorin. Rezhim dostupa: http://rpsc.ru/publications/history/atorin_pomestnyj_sobor1971/ 
Vpervye posle raskola [Elektronnyj resurs]. - Rezhim dostupa: https://lenta.ru/articles/2017/05/31/old_believers/

Vlasti pomogut staroobryadcam otprazdnovat' yubilej protopopa Avvakuma [Elektronnyj resurs]. - Rezhim dostupa: https://ria.ru/20160623/1449858177.html.

Dnevniki imperatora Nikolaya II. - M.: Orbita, 1991. - 755 s.

Zhitie Avvakuma i drugie ego sochineniya / sost., vstup. st. i komment. A. N. Robinson. - M.: Sov. Rossiya, 1991. - 368 s.

Ibneeva G. V. Staroobryadcheskoe naselenie Nizhegorodskogo kraya: opyt politicheskogo vzaimodejstviya / G. V. Ibneeva // Pravoslavnyj sobesednik. - Vyp. 1(9). - 2005. - S. 72-98.

Ivanov-Ordynskij V. Fal'sifikaciya ili otkroveniya prosveshchennoj imperatricy? / V. IvanovOrdynskij [Elektronnyj resurs]. - Rezhim dostupa: https://vk.com/topic-10399682_22777022.

Mitropolit Kornilij: uchastie staroobryadcev v revolyucii - mif [Elektronnyj resurs]. - Rezhim dostupa: https://ria.ru/20170203/1487123742.html.

Petrov V. L. Kratkoe slovo o protopope Avvakume / V. L. Petrov // Istoriya i kul'tura semejskih Zabajkal'ya. Hrestomatiya. Ch. II. - Ulan-Ude: Belig, 2007. - S. 8-20.

Petrova E. V. Sociokul'turnaya adaptaciya semejskih Zabajkal'ya (etnosociologicheskij analiz) / E. V. Petrova. - Ulan-Ude: Izd-vo BNC SO RAN, 1999. - 127 s.

Petrova E. V. Sovremennoe zabajkal'skoe staroobryadchestvo: uch. pos. / E. V. Petrova. Ulan-Ude: Izd-vo BGU, 2005. - $182 \mathrm{~s}$.

Potashenko G. V. Staroverie v Litve: vtoraya polovina XVII - nachalo IX vv.: issledovaniya, dokumenty i materialy / G. V. Potashenko. - Vilnius: Aidai, 2006. - 543 s.

Prigarin A. A. Russko-tureckaya vojna 1806-1812 gg. i sud'by nekrasovcev / A. A. Prigarin // Rusin. - 2012. - № 2(28). - S. 5-16.

Rasponin I. Staroobryadchestvo v XVIII-XIX [Elektronnyj resurs] / I. Rasponin. - Rezhim dostupa: http://rpsc.ru/publications/history/staroobrjadchestvo_xviii-xix/

Rech' imperatricy Ekateriny Velikoj o staroobryadchestve, skazannaya na obshchej konferencii Sinoda i Senata 15 sentyabrya 1763 goda. - M.: Tip. P. P. Ryabushinskago, 1912. - 44 s.

Russkoe pravoslavie: vekhi istorii / nauch. red. A. I. Klibanov. - M: Politizdat, 1989. - 719 s.

Smirnov P. S. Vnutrennie voprosy v raskole v XVII v. Issledovanie iz nachal'noj istorii raskola po vnov' otkrytym pamyatnikam, izdannym i rukopisnym / P. S. Smirnov. - SPb.: Pechatnya S. P. Yakovleva, 1898. - 517 s.

Staroobryadcy (semejskie) Buryatii: istoriko-kul'turnyj enciklopedicheskij spravochnik. Ulan-Ude: Ekos, 2015. - 264 s. 